University of Nebraska - Lincoln

DigitalCommons@University of Nebraska - Lincoln

$10-2001$

Description of Buckarootrema goodmani n. g., n. sp. (Digenea:

Pronocephalidae), a Parasite of the Freshwater Turtle Emydura macquarii (Gray, 1830) (Pleurodira: Chelidae) from Queensland, Australia, and a Phylogenetic Analysis of the Genera of the Pronocephalidae Looss, 1902

Thomas R. Platt

St. Mary's College

Daniel R. Brooks

University of Toronto,dnlbrooks@gmail.com

Follow this and additional works at: https://digitalcommons.unl.edu/parasitologyfacpubs

Part of the Parasitology Commons

Platt, Thomas R. and Brooks, Daniel R., "Description of Buckarootrema goodmani n. g., n. sp. (Digenea: Pronocephalidae), a Parasite of the Freshwater Turtle Emydura macquarii (Gray, 1830) (Pleurodira: Chelidae) from Queensland, Australia, and a Phylogenetic Analysis of the Genera of the Pronocephalidae Looss, 1902" (2001). Faculty Publications from the Harold W. Manter Laboratory of Parasitology. 238. https://digitalcommons.unl.edu/parasitologyfacpubs/238

This Article is brought to you for free and open access by the Parasitology, Harold W. Manter Laboratory of at DigitalCommons@University of Nebraska - Lincoln. It has been accepted for inclusion in Faculty Publications from the Harold W. Manter Laboratory of Parasitology by an authorized administrator of DigitalCommons@University of Nebraska - Lincoln. 


\title{
DESCRIPTION OF BUCKAROOTREMA GOODMANI N. G., N. SP. (DIGENEA: PRONOCEPHALIDAE), A PARASITE OF THE FRESHWATER TURTLE EMYDURA MACQUARII (GRAY, 1830) (PLEURODIRA: CHELIDAE) FROM QUEENSLAND, AUSTRALIA, AND A PHYLOGENETIC ANALYSIS OF THE GENERA OF THE PRONOCEPHALIDAE LOOSS, 1902
}

\author{
Thomas R. Platt and Daniel R. Brooks* \\ Department of Biology, Saint Mary's College, Notre Dame, Indiana 46556.
}

\begin{abstract}
Buckarootrema goodmani n. g., n. sp. is described from the small intestine of the Murray turtle, Emydura macquarii (Gray, 1830), from the vicinity of Warwick, Queensland, Australia. The distinctive taxonomic features include the vitellarium, which consists of 2 compact masses directly anterior to and occasionally overlapping the testes; the uterus with extensive preand postovarian coils; intestinal ceca with small, medial diverticula that terminate anterior to or at the anterior margin of the testes; a comma-shaped cirrus sac with both internal and external seminal vesicles. Phylogenetic systematic analysis of the genera of the Pronocephalidae including Buckarootrema and Notopronocephalus, the only other genus of pronocephalids reported from Australian freshwater turtles, indicates that Buckarootrema is the sister taxon of Neopronocephalus and Notopronocephalus is the sister group of the rest of the Pronocephalinae.
\end{abstract}

The helminth fauna of Australian freshwater turtles is poorly known. Whereas species of the family Pronocephalidae Looss, 1902 have been reported from both marine and freshwater turtles worldwide, only a single representative of this family is reported from Australia (Cribb and Pichelin, 1997). During an examination of turtles from southern Queensland, numerous specimens of a pronocephalid were collected that cannot be assigned to any currently recognized genus in the family. They are herein described as Buckarootrema goodmani n. g., n. sp.

\section{MATERIALS AND METHODS}

Eleven Emydura macquarii (Gray, 1830) were captured on 19 February 1994 in wire traps baited with meat scraps and partially submerged near the shoreline of Leslie Dam. Turtles were returned to the laboratory and held in tanks until necropsy, which were completed 20 23 February 1994. Turtles were injected with a lethal dose of sodium pentabarbitone and examined for helminths using standard procedures.

Parasites were killed and fixed unflattened in hot 5\% formalin, stained in Van Cleave's hematoxylin (Pritchard and Kruse, 1982), and mounted as whole mounts in Canada balsam. One unstained specimen was dehydrated through an ethanol series to $100 \% \mathrm{EtOH}$ and then crushed to release eggs. The eggs were then cleared in methyl salicylate and mounted in Canada balsam. Figures were made with the aid of a drawing tube. All measurements are in micrometers, and given as the mean followed by the range in parentheses. The following specimens were examined for comparative purposes: Pleurogonius malaclemys Hunter, 1961 (holotype: USNPC no. 39052) and Notopronocephalus peekayi Cribb and Pichelin, 1997 (paratypes: QM [Queensland Museum] nos. G 213521, G 213524, and G 2123526).

A new phylogenetic analysis of the Pronocephalidae was performed, adding Notopronocephalus and Buckarootrema to the analysis of PérezPonce de León and Brooks (1995), along with the following new character information:

Character 39 of Pérez-Ponce de León and Brooks (1995). This was listed as thickened epithelial lining of esophageal walls, but should have been listed as thickened epithelial lining of cecal walls. Macravestibulum, Choanoporus, Ruicephalus, Neopronocephalus, and Buckarootre$m a$ exhibit the apomorphic condition of thickened cecal walls.

Character 43 of Pérez-Ponce de León and Brooks (1995) (relative number of vitelline follicles). Many in each vitellarium (0), few in each vitellarium (1); each vitellarium compact (2) [new character state].

Received 27 November 2000; revised 19 March 2001; accepted 19 March 2001.

* Department of Zoology, University of Toronto, Toronto, Ontario, Canada M5S 1A1.
Character 48 (new character). Little or no posttesticular uterine coiling (0); extensive posttesticular uterine coiling (1). The apomorphic condition is found in Neopronocephalus and Buckarootrema..

Character 49 (new character). Cirrus sac straight or spherical (0); cirrus sac comma-shaped (1). This is an autapomorphy for Buckarootrema.

Finally, the data matrix presented by Pérez-Ponce de León and Brooks (1995) contained 48 columns of characters. The last column should have been deleted. Therefore, the 2 new characters above become characters 48 and 49 in the new data matrix (Table I).

\section{DESCRIPTION}

Buckarootrema n. gen.

Diagnosis: Pronocephalidae Looss, 1902 (sensu Pérez-Ponce de León and Brooks [1995]). Body small, delicate, posterior end rounded, without posterior projections. Tegument aspinous. Head collar present. Oral sucker and mouth subterminal. Esophagus long, thin-walled, slightly expanded at cecal bifurcation. Cecal walls thickened, with small medial diverticula. Ceca terminating anteriorly near mid-region of vitellaria anterior to testes, occasionally extending to anterior testicular margin. Testes 2, oval; opposite to oblique; a short distance from posterior end. Cirrus-sac dextral, intracecal, comma-shaped, containing large oval pars prostatica with luminal projections, and internal seminal vesicle; ejaculatory duct long, sinuous. Cirrus aspinous. External seminal vesicle elongate, transverse. Metraterm elongate, muscular. Male and female ducts joining to form common genital pore; pore intercecal, sinistral. Ovary round to oval; dextral, pretesticular. Mehlis' gland, ootype, Laurer's canal not observed. Vitellarium comprising 2 compact masses immediately anterior to, or overlapping, testes. Uterus extensive, occupying all intracecal space. Excretory vesicle a short-stemmed Y. Excretory pore terminal. Eggs oval, operculate, with 1 long polar projection at each end.

Etymology: The genus name is derived from the Buckaroo Motel, Warwick, Queensland, the staging site for turtle collection.

Type-species: Buckarootrema goodmani n. sp.

\section{Buckarootrema goodmani n. sp.}

(Figs. 1-3)

Measurements based on 12 stained whole mounts. Body small, delicate, tegument aspinous. Lateral margins of anterior third folded medially forming shallow depression, posterior end rounded, plump. Total length 809 (762-856); anterior width 269 (245-287), posterior width 297 (271-324). Cephalic collar well-developed, with ventral incision; no indication of dorsal interruption. Oral sucker slightly oval, 60 (58$63) \times 64(60-68)$; mouth subterminal. Esophagus narrow, straight 179 (163-198) long, dilated at cecal junction. Ceca thick-walled, slightly sinuous, with small medial diverticula along anterior half. Ceca short, 
TABLE I. Data matrix for phylogenetic analysis of Pronocephalidae genera and 4 outgroup taxa* and 49 characters. (Character 5 is omitted in analyses). For identities of characters and character states, see text and Perez-Ponce de Leon and Brooks (1995).

\begin{tabular}{lllllll}
\hline MI & 0000000000 & 0000000000 & 0000000000 & 0000000000 & 000000000 \\
NO & 0011001201 & 0000000000 & 1100000100 & 0001000000 & 000000000 \\
PA & 0001111201 & 0000000000 & 0000000100 & 0001000000 & 000000000 \\
NT & 0011111201 & 0000000000 & 0000000100 & 0001000000 & 000000000 \\
AD & 0012401110 & 0000100100 & 0000000100 & 0001000000 & 000000200 \\
Pa & 0010011111 & 1100000110 & 0000000100 & 0001000000 & 000000000 \\
Pb & 0010111110 & 1100000110 & 0000000100 & 0001000000 & 000000000 \\
Pc & 0010111111 & 1110000110 & 0010000100 & 0001000000 & 000000000 \\
IG & 0010111111 & 1100111110 & 0010000100 & 0001000000 & 000000000 \\
RE & 0010111111 & 1110000011 & 1000100100 & 0001000000 & 000000000 \\
PP & 0010011111 & 1110000110 & 1200000100 & 0001000000 & 000000000 \\
PY & 0010211110 & 1111000100 & 0011001100 & 0001000000 & 000110000 \\
CR & 0012611111 & 1110001200 & 0010110100 & 0001000000 & 000011000 \\
PS & 0010210111 & 1110100200 & 0010001100 & 0001000000 & 000011000 \\
BA & 0110511111 & 1110100200 & 0010001100 & 0001000000 & 000011000 \\
CH & 0110311112 & 1100000100 & 0000000011 & 0001000000 & 000000000 \\
DE & 0112511112 & 1110000100 & 0000000010 & 1101000000 & 000000000 \\
DI & 0210211112 & 1110000100 & 0000000010 & 1011000000 & 000000000 \\
PR & 0200201111 & 1000000100 & 0000000100 & 0000000000 & 000100000 \\
RU & 1200001111 & 1000000100 & 0000000100 & 0001111010 & 011100100 \\
CE & 1200001111 & 1000000100 & 0000000100 & 0002110100 & 000100100 \\
ME & 1200001110 & 1000000100 & 0000000100 & 0002110100 & 000100100 \\
NE & 1200001010 & 1000000100 & 0000000100 & 0101110010 & 011100110 \\
BT & $10 ? ? 701100$ & 1000100110 & 1110000100 & $00 ? 110 ? 010$ & 012100111 \\
MA & 1200101111 & 1000000100 & 0000000100 & 0001110011 & 000100100 \\
CP & 1200101111 & 1000000100 & 0000000100 & 0001110011 & 100100100 \\
NP & $00 ? 0001110$ & 1000110110 & 0200001000 & 0011000000 & 000100000 \\
\hline
\end{tabular}

$*-\mathrm{DT}=$ Deuterobaridinae $; \mathrm{NO}=$ Notocotylidae $; \mathrm{PA}=$ Parapronocephalum $; \mathrm{NT}=$ Notocotyloides $; \mathrm{AD}=$ Adenogaster $; \mathrm{PL}=$ Pleurogonius $;$ HI = Himasomum $; \mathrm{IG}$ $=$ Iguanacola $; \mathrm{RE}=$ Renigonius $; \mathrm{PP}=$ Parapleurogonius $; \mathrm{PY}=$ Pyleosomum $; \mathrm{CR}=$ Cricocephalus $; \mathrm{PS}=$ Pseudobarisomum $; \mathrm{BA}=$ Barisomum $; \mathrm{CH}=$ Charaxi cephalus $; \mathrm{DE}=$ Desmogonitus $; \mathrm{DI}=$ Diaschistorchis $; \mathrm{PR}=$ Pronocephalus $; \mathrm{RU}=$ Ruicephalus $; \mathrm{CE}=$ Cetiosaccus $; \mathrm{ME}=$ Metacetabulum $; \mathrm{NE}=$ Neopronocephalus $;$ $\mathrm{BT}=$ Buckarootrema $; \mathrm{MA}=$ Macravestibulum $; \mathrm{CP}=$ Choanophorus $; \mathrm{NP}=$ Notopronocephalus. $0=$ plesiomorphic state; $1-7=$ derived states.

terminating in middle of vitelline field, rarely reaching anterior testicular margin; right cecum $239(200-273)$ and left cecum $(n=10) 243(225-$ 271) from posterior end, respectively. Testes 2, oval; opposite to oblique. Right testis $136(113-155) \times 86(55-100)$, left testis 129 (113$145) \times 85$ (55-100). Cirrus sac large, dextral, intracecal, commashaped, $245(218-275) \times 56(53-63)(\mathrm{n}=9)$; containing large oval pars prostatica with numerous internal glandlike processes, and a sinuous eversible ejaculatory duct; internal seminal vesicle present. External seminal vesicle elongate, transverse. Male and female terminal ducts fuse to form a common genital pore opening ventrally, intercecal, sinistral to mid-line, 317 (298-339) from anterior end. Ovary dextral, round to oval $82(63-115) \times 71(60-85)$, pretesticular; ootype, Mehlis' gland, and Laurer's canal not seen. Vitellaria forming 2 compact masses just anterior to or overlapping anterior margin of testes; right vitellarium $141(105-185) \times 78$ (55-98), left vitellarium $143(113-188) \times 78(55-$ 98). Uterus extensive, predominantly intracecal, occasionally extracecal, filling post- and preovarian space from posterior end to distal end of cirrus sac; metraterm long, muscular, surrounded by glandular cells, fuses with male duct. Excretory vesicle Y-shaped with short stem, excretory pore terminal. Uterine eggs $(\mathrm{n}=9)$ oval $30(28-33) \times 15$, operculate, with a single polar process at each end. Opercular process longer $139(115-158)$ than abopercular $97(75-113)(n=4)$.

\section{Taxonomic summary}

Type host: Emydura macquarii (Gray, 1830) (Testudines: Pleurodira: Chelidae).

Type locality: Leslie Dam, Warwick, Queenland, Australia $\left(25^{\circ} 01^{\prime} \mathrm{S}\right.$, $\left.152^{\circ} 55^{\prime} \mathrm{E}\right)$.

Specimens deposited: Queensland Museum (QM), Brisbane, Queensland, Australia: QM no. G218191 (holotype); QM nos. G218192-96 (5 paratypes); United States National Parasite Collection (USNPC), Belts- ville, Maryland: USNPC nos. 91112 (2 paratypes), 91113 (4 paratypes). Additional specimens in the first author's collection.

Infection site: Small intestine.

Etymology: The specific name goodmani is in honor of Dr. John A. Goodman, Professor Emeritus, University of Redlands, for his contributions to parasitology during the past $50 \mathrm{yr}$.

\section{Remarks}

Buckarootrema goodmani n. gen., n. sp. differs from all other genera in the Pronocephalidae sensu Pérez-Ponce de León and Brooks (1995) by having a curved rather than straight or spherical cirrus sac. It differs from all other species except Pleurogonius malaclemys Hunter, 1961 described from the diamondback terrapin, Malaclemys terrapin (Schoepff, 1793), a brackish water turtle found along the southern Atlantic and Gulf coasts of the United States (Ernst and Barbour, 1989) in having 2 compact vitellaria slightly overlapping the testes near the posterior end of each worm (Hunter, 1961). Possession of extracecal testes and a relatively short cirrus sac places the new species as a member of the Pronocephalinae sensu Pérez-Ponce de León and Brooks (1995). Within that group, it resembles Choanoporus, Macravestibulum, Ruicephalus, and Neopronocephalus, in having thickened epithelial lining of the ceca and, within that group, it resembles Ruicephalus and Neopronocephalus in having uterine loops between the testes and ovary and a relatively small number of vitelline follicles (the compact vitellaria are interpreted as a further modification of having fewer vitelline follicles). Finally, it most closely resembles Neopronocephalus by having eggs with single bipolar filaments and extensive postovarian uterine coiling (see Brooks and Palmieri, 1979). Thus, the new species appears to be the sister group of Neopronocephalus. In addition to the features listed above, the new species differs from Neopronocephalus in having testes at the posterior end of the body, a single genital pore, arms of 

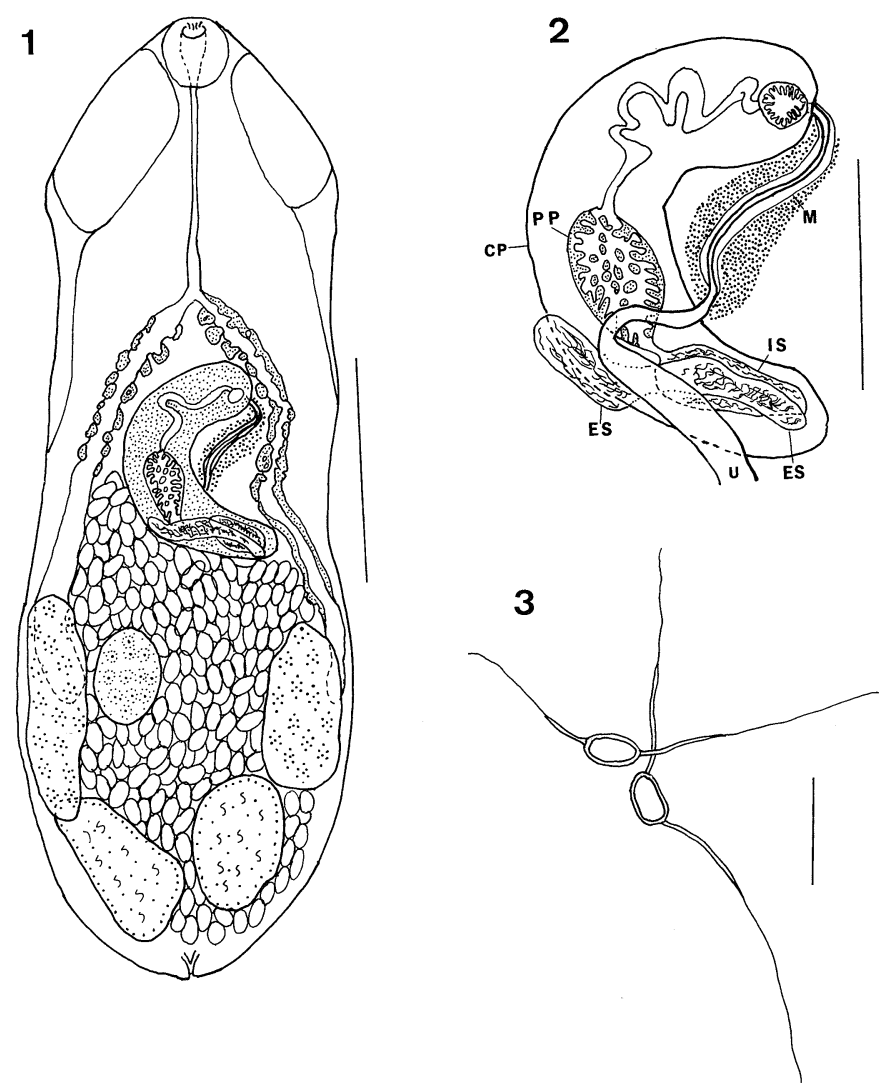

FIGURES 1-3. Buckarootrema goodmani n. sp. 1. Adult, ventral (holotype) (eggs drawn free hand, not to scale). 2. Terminal genitalia, ventral (paratype). 3. Ova (uterine, dissected from preserved specimen). Scale bars: $1=200 \mu \mathrm{m} ; 2=100 \mu \mathrm{m} ; 3=50 \mu \mathrm{m}$. Abbreviations: $\mathrm{cp}$, cirrus pouch; pp, pars prostatica; is, internal seminal vesicle; es, external seminal vesicle; $\mathrm{m}$, metraterm; $\mathrm{u}$, uterus.

the excretory system not united anteriorly, relatively long esophagus, ceca terminating at the anterior margins of the testes, extracecal uterine loops, and no posterior vestibule.

A striking feature of the new species is the extent of the uterus and the large numbers of eggs contained in even the smallest individuals. In many specimens, including one measuring slightly over $600 \mu \mathrm{m}$, the eggs obscure most structures from the posterior half of the cirrus sac to the posterior end of the worm. Posttesticular coiling is variable in $B$. goodmani. The uterus may extend only to the posterior margin of the testes or occupy some space posterior to the testes. Either testicular location and development prohibits the uterus from extending posteriorly, or uterine development prevents the testes from locating further posteriad. This issue cannot be resolved on the basis of the material at hand. Prevalence in this 1-day sample was $45.5 \%$ (5/11) with a mean intensity of 56.4 worms per infected host. Individual intensities, however, varied considerably, with 6 turtles lacking $B$. goodmani, 3 individuals harboring small numbers $(3,5,5)$, and 2 animals with 102 and 167 worms, respectively.

\section{RESULTS}

Phylogenetic systematic analysis of the new data matrix produced 122 most parsimonious trees (MPTs). Pérez-Ponce de León and Brooks (1995) excluded character 5 (cecal diverticula) because of ambiguity in descriptions; doing so in this case reduces the number of MPTs to 6, as it did in the analysis by Pérez-Ponce de León and Brooks (1995). Each of these 6 MPTs places Buckarootrema as the sister group of Neopronocephalus and Notopronocephalus as the sister group of the Pronocephalinae sensu Pérez-Ponce de León and Brooks (1995). The strict consensus tree (Fig. 4) shows the relative relationships among the members of the Pronocephalinae, indicating the placement of Buckarootrema and Notopronocephalus. They are otherwise identical to the 6 MPTs reported by Pérez-Ponce de León and Brooks (1995). Rather than propose a subfamily whose diagnosis would be redundant with the diagnosis for Notopronocephalus, we include Notopronocephalus within the Pronocephalinae.

Pérez-Ponce de León and Brooks (1995) presented the only previous phylogenetic systematic analysis of generic relationships among the Pronocephalidae. They reported 6 MPTs, each with a consistency index of $73.5 \%$. The 6 MPTs differed only in the relative relationships among members of Pleurogonious, Iguanacola, and Renigonius + Parapleurogonius. Pérez-Ponce de León and Brooks (1995) suggested at the time that this might be because Pleurogonius was paraphyletic. The discovery of $N$. peekayi Cribb and Pichelin 1997 and B. goodmani illustrates the impact that such ambiguity can have on a larger group.

\section{DISCUSSION}

The most significant finding of the new analysis is the large amount of homoplasy introduced by the inclusion of the new species from Australia. The 6 MPTs reported by Pérez-Ponce de León and Brooks (1995) each had a consistency index (CI) of $73.5 \%$ for the ingroup, whereas the $6 \mathrm{MPTs}$ in this analysis each have a CI of $64 \%$. Normally, such a decrease in the CI would produce multiple additional MPTs. This does not happen in this instance because the bulk of the homoplasy is autapomorphic for Notopronocephalus and Buckarootrema in the Pronocephalinae and for various members of Pleurogonius, Iguanacola, Renigonius, and Parapleurogonius in the Charaxicephalinae. This ambiguity is due to the status of the members of Pleurogonius relative to species in Iguanacola and Renigonius + Parapleurogonius, as first noted by Pérez-Ponce de León and Brooks (1995), and not N. peekayi or B. goodmani per se. If Pleurogonius, Iguanacola, Renigonius, and Parapleurogonius are removed from the analysis, a single MPT with a CI of $71.6 \%$ is obtained that does not change any of the relative relationships of the remaining taxa. Elimination of character 48 (extent of uterine coiling) has no effect on the resulting hypothesis.

Cribb and Pichelin (1997) reported difficulty in placing Notopronocephalus within a subfamily, whereas the current analysis places the genus as the sister group of all other Pronocephalinae. Cribb and Pichelin's dilemma is reproduced, however, by removing the information provided by the 4 outgroup taxa, which form 2 paraphyletic groups. This produces 2 alternative resolutions, one placing Notopronocephalus as the sister group of the rest of the Pronocephalinae and the other placing Notopronocephalus as the sister group of the Pronocephalinae + Charaxicephalinae. This could be interpreted, using nonphylogenetic terms, as Notopronocephalus being "intermediate" between the Charaxicephalinae and Pronocephalinae on the one hand, and the Adenogasterinae on the other. This particular problem is due to homoplasy in some traits shared by Notopronocephalus and Iguanacola that cannot be resolved without the stability provided by proper outgroup comparisons. In their 


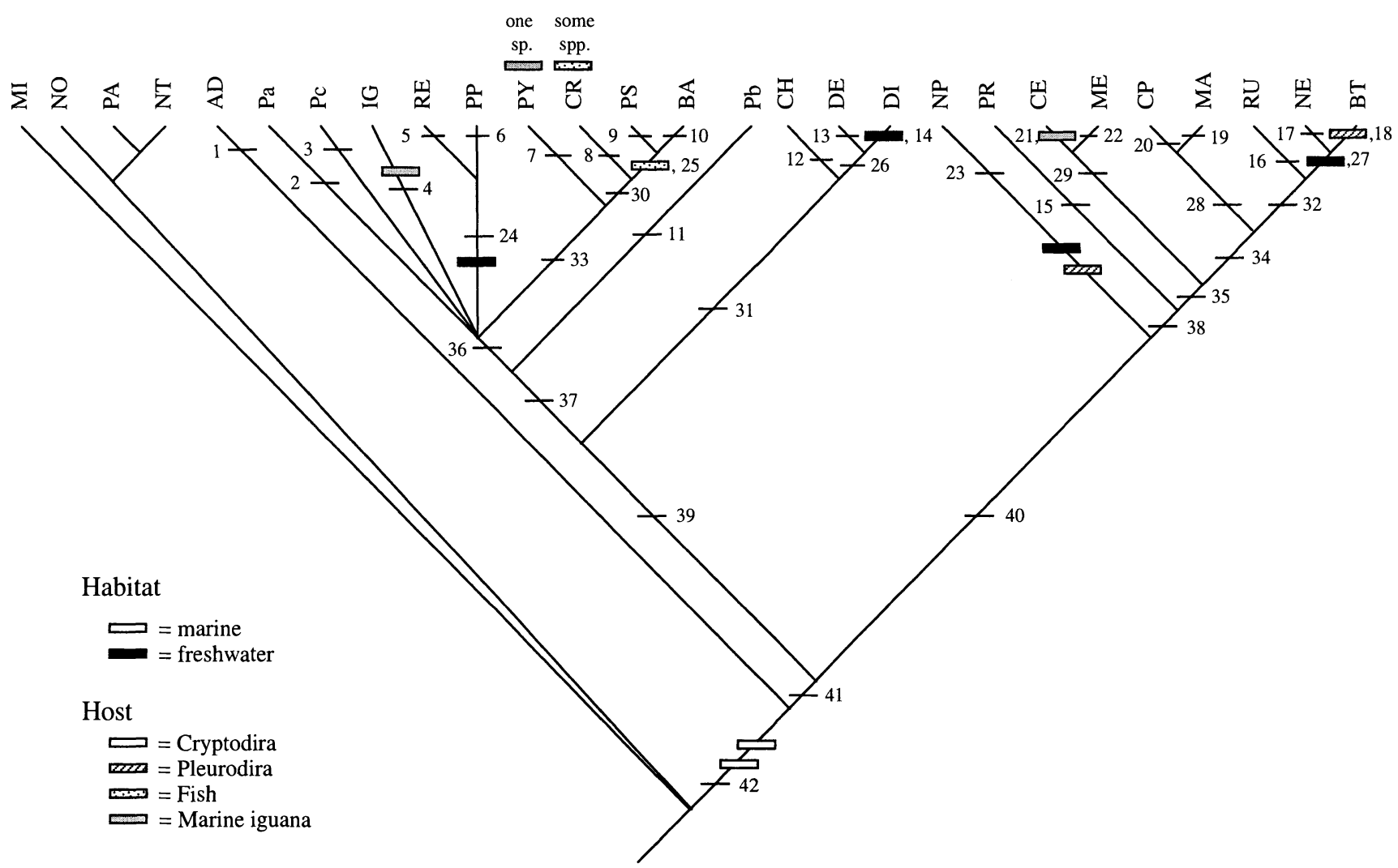

FIGURE 4. Strict consensus tree (of 6 most parsimonious trees) for genera of Pronocephalinae on the basis of phylogenetic systematic analysis of matrix in Table I, excluding character 5. DB = Deuterobaridinae; NO = Notocotylidae; PA = Parapronocephalum; AD = Adenogaster; Pa $=$ Pleurogonius $\mathrm{A} ; \mathrm{Pb}=$ Pleurogonius $\mathrm{B} ; \mathrm{Pc}=$ Pleurogonius $\mathrm{C} ; \mathrm{IG}=$ Iguanacola $; \mathrm{RE}=$ Renigonius $; \mathrm{PP}=\mathrm{Parapleurogonius;} \mathrm{PY}=$ Pyelosomum; $\mathrm{CR}=$ Cricocephalus $; \mathrm{PS}=$ Pseudobarisomum $; \mathrm{BA}=$ Barisomum $; \mathrm{CH}=$ Charaxicephalus $; \mathrm{DE}=$ Desmogonius $; \mathrm{DI}=$ Diaschistorchis $; \mathrm{PR}=$ Pronocephalus; $\mathrm{RU}=$ Ruicephalus $; \mathrm{CE}=$ Cetiosaccus $; \mathrm{ME}=$ Metacetabulum $; \mathrm{BT}=$ Buckarootrema $; \mathrm{NE}=$ Neopronocephalus $; \mathrm{MA}=$ Macravestibulum; $\mathrm{CP}=$ Choanoporus $; \mathrm{NT}=$ Notopronocephalus. Numbers on branches (bold) refer to the following putative apomorphies (listed as character number-character state): $1: 4-2 ; 15-1 ; 46-2 ; 2: 13-0 ; 3: 23-1 ; 4: 15-1 ; 16-1 ; 17-1 ; 23-1 ; 5: 13-0 ; 18-0 ; 20-1 ; 25-1 ; 6: 22-2 ; 7: 14-1 ; 24-$ $1 ; 44-1 ; 8: 4-2 ; 10-0 ; 17-1 ; 25-1 ; 26-1 ; 27-0 ; 9: 7-0 ; 10: 2-1 ; 12: 30-1 ; 13: 32-1 ; 14: 2-2 ; 33-1 ; 15: 34-0 ; 16: 37-1 ; 17: 8-0 ; 32-1 ; 18: 2-0 ; 4-0$; $9-0 ; 15-1 ; 19-1 ; 21-1 ; 22-1 ; 23-1 ; 36-0 ; 43-2 ; 49-1 ; 20: 41-1 ; 22: 10-0 ; 23: 15-1 ; 16-1 ; 19-1 ; 22-2 ; 27-1 ; 28-0 ; 33-1 ; 24: 21-1 ; 25: 15-1 ; 26: 13-$ $1 ; 31-1 ; 27: 27-0 ; 48-1 ; 28: 40-1 ; 29: 34-2 ; 38-1 ; 30: 18-2 ; 46-1 ; 31: 2-1 ; 10-2 ; 28-0 ; 29-1 ; 32: 42-1 ; 43-1 ; 33: 19-0 ; 23-1 ; 27-1 ; 45-1 ; 34: 39-$ $1 ; 35: 1-1 ; 10-1 ; 35-1 ; 36-1 ; 47-1 ; 36: 10-1 ; 37: 19-1 ; 38: 2-2 ; 39: 6-1 ; 12-1 ; 40: 3-0 ; 44-1 ; 41: 11-0 ; 42: 8-1 ; 9-1 ; 18-1$. Notations on the tree indicate most parsimonious explanations for habitat $(\mathrm{M}=$ marine, $\mathrm{F}=$ freshwater $)$ and host switches $(\mathrm{C}=$ Cryptodira; $\mathrm{P}=\mathrm{Pleurodira})$ associated with the origins of Notopronocephalus and Buckarootrema. The plesiomorphic conditions (M and C) are based on functional outgroup comparisons; the Charaxicephalinae and Adenogasterinae are plesiomorphically found in marine cryptodire turtles (Chelonidae).

classic discussion of outgroup comparisons, Maddison et al. (1984) strongly emphasized that the robustness of phylogenetic systematic analyses could be enhanced tremendously by using at least 2 paraphyletic outgroups (see also Brooks and McLennan, 1991, in press; Wiley et al., 1991, in press). The present study thus represents a graphic corroboration of their insight, as it is the use of the paraphyletic outgroup taxa that permit a robust placement of Notopronocephalus even in the presence of the substantial homoplasy between Iguanacola and Notopronocephalus.

The new phylogenetic tree suggests that the 2 pronocephalids currently known to inhabit Australian freshwater turtles, $N$. peekayi and B. goodmani, are the result of independent habitat switches from marine to freshwater, and of host switches (summarized in Fig. 4) from a relatively younger chelonian lineage (Cryptodira) to a relatively older one (Pleurodira) (see Ernst and Barbour, 1989).

\section{ACKNOWLEDGMENTS}

T.R.P. thanks Tom Cribb and Sylvie Pichelin, University of Queensland, for their assistance in the field and generous hospitality, and the Lilly Foundation for their support of a sabbatical leave. D.R.B. acknowledges support from the Natural Sciences and Engineering Research Council (NSERC) of Canada. We thank Deborah A. McLennen, University of Toronto, for preparing Figure 4.

\section{LITERATURE CITED}

Brooks, D. R., And D. A. McLennan. 1991. Phylogeny, ecology and behavior: A research program in comparative biology. University of Chicago Press, Chicago, Illinois, 434 p.

, AND - 2002. The nature of diversity: A voyage through space and time. University of Chicago Press, Chicago, Illinois, in press.

, AND J. R. PALMIERI. 1979. Neopronocephalus orientalis sp. n. (Digenea: Pronocephalidae) and Spirhapalum elongatum Rohde, Lee and Lim, 1968 (Digenea: Spirorchiidae) from Cuora amboi- 
nensis (Daudin) in Malaysia. Proceedings of the Helminthological Society of Washington 46: 55-57.

CRIBB, T. H., AND S. P. PICHELIN. 1997. Notopronocephalus peekayi gen. et sp. n. (Digenea: Pronocephalidae) from Australian freshwater turtles. Folia Parasitologica 44: 279-282.

ERnst, C. H., AND R. W. BARBour. 1989. Turtles of the world. Smithsonian Institution Press, Washington, DC, 313 p.

Hunter, W. S. 1961. A new monostome, Pleurogonius malaclemys, $\mathrm{n}$. sp. (Trematoda: Pronocephalidae) from Beaufort, North Carolina. Proceedings of the Helminthological Society of Washington 28: $111-114$.

Maddison, W. P., M. J. Donoghue, And D. R. Maddison. 1984. Outgroup analysis and parsimony. Systematic Zoology 33: 83-103.
Pérez-Ponce de León, G., AND D. R. Brooks. 1995. Phylogenetic relationships of the genera of Pronocephalidae Looss, 1902 (Digenea: Paramphistomiformes). Journal of Parasitology 81: 267-277.

Pritchard, M. H., and G. O. W. Kruse. 1982. The collection and preservation of animal parasites, Technical Bulletin No. 1. University of Nebraska Press, Lincoln, Nebraska, 141 p.

Wiley, E. O., D. J. Siegel-Causey, D. R. BRooks, and V. A. Funk. 1991. The compleat cladist: A primer of phylogenetic procedures, 1st ed. Special Publication of the Museum of Natural History, University of Kansas, Lawrence, Kansas, 158 p.

,-- , AND - 2001. The compleat cladist: A primer of phylogenetic procedures, 2nd ed. Special Publication of the Museum of Natural History, University of Kansas, Lawrence, Kansas, in press. 